\title{
Monitoring System for a Street Lighting Luminaire
}

\author{
Sistema de Monitoreo Para una Lámpara de Alumbrado Público
}

\author{
Harryson Ramírez Murillo ${ }^{(D)} 1^{*} \quad$ | Iván Alberto Arias Galvis ${ }^{2^{*}}$ | \\ Alfonso Germán Garzón Huertas ${ }^{3 *}$
}

${ }^{1}$ Programa de Ingeniería Eléctrica de la Universidad de La Salle, Bogotá, Colombia.

${ }^{2}$ Programa de Ingeniería Electrónica, Universidad Autónoma de Manizales, Manizales, Colombia

${ }^{3}$ Facultad de Ingeniería Mecánica, Electrónica y Biomédica (FIMEB), Universidad Antonio Nariño, Manizales, Colombia

\section{Correspondence}

Harryson Ramírez Murillo, Programa de Ingeniería Eléctrica de la Universidad de La Salle, Bogotá, Colombia.

Email: haramirez@unisalle.edu.co

Copyright : Licencia de Creative Commons Reconocimiento-NoComercial 4.0 Interna.

\section{cc) coreative}

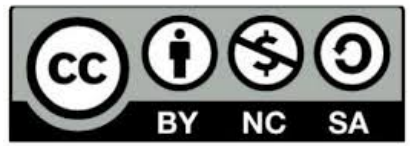

Editors: Robert Paul Salazar, Luz Adriana Suárez Suárez, Germán Chaparro Molano.

How to cite

Ramírez H., Arias I., Garzón A., Monitoring System for a Street Lighting Luminaire,

TECCIENCIA, Vol. 14, No. 27, 33-42, 2019

DOI:http://dx.doi.org/10.18180/tecciencia.2019.27.4

\section{1 | INTRODUCTION}

Public services are a basic necessity in contemporary society, amongst which is street lighting, which is of great importance since it provides safety to the pedestrian and vehicular flow, providing an adequate visibility in the streets, public parks and other spaces with free circulation in the night. Although today technological

*Equally contributing authors.
ABSTRACT. This research work shows a monitoring system for a public lighting luminaire. This system allows reducing time response under different kind of faults, such as short circuits in one of luminaries' components. On the other hand, this development could contribute to improve the roads, pedestrian and vehicles safety. The proposed prototype has two microcontrollers which were used for transmitting $(\mathrm{TX})$ and receiving (RX) devices, respectively. Likewise, it requires a luxes (IX) and current (A) sensors, real-time module, external memory and GSM devices. The Technical Regulation of Lighting and Street Lighting (RETILAP) states that is possible making a preventive maintenance when the luminaire efficiency is below than the $70 \%$, which corresponds to 0.7 A current. Nowadays, is very important saving energy and using properly the environmental resources, due to the increasing of global warming effect.

keywords: Monitoring, Street Lighting, Luxes, Luminary, lluminance.

RESUMEN. Este trabajo de investigación muestra un sistema de monitoreo para una luminaria de alumbrado público. Este sistema permite reducir la respuesta nentes de las luminarias. Por otro lado, este desarrollo podría contribuir a mejorar las carreteras, la seguridad de los peatones y los vehículos. El prototipo propuesto tiene dos microcontroladores que se utilizaron como dispositivos para transmitir (TX) y recibir (RX), respectivamente. Así mismo, requiere de sensores de luxes (IX) y de corriente (A), módulo en tiempo real, memoria externa y de dispositivos GSM. El Reglamento Técnico de lluminación y Alumbrado Público (RETILAP) establece que es posible realizar un mantenimiento preventivo cuando la eficiencia de la iluminación es inferior al $70 \%$, lo cual corresponde a una corriente de 0.7 A. Hoy en día, es muy importante ahorrar energía y utilizar adecuadamente los recursos ambientales, debido al aumento del efecto del calentamiento global.

Palabras clave: Monitoreo, Alumbrado Público, Luxes, Luminaria, lluminancia. de tiempo en diferentes tipos de fallas, como cortocircuitos en uno de los compo- 
advancements are present in several applications in everyday life, a system that detects and helps prevent failures in lighting systems has not been stablished yet. Hence, usually two types of failures are present: Luminaires are off during the night, and luminaires on during the day. So, its relevant developing a system that impacts in the public service provision, abide by the rules for public street lighting stablished by the designed organisms, such as the Ministry of Mines and Energy in Colombia. Amongst the main regulations are:

a. The 1991 Political Constitution of Colombia in article 365 defines that the public services are inherent to the State's social purpose, and that is the State's duty to ensure their efficient provision to all inhabitants of the National territory [1].

b. Decree 2424 of 2006 regulates the street lighting service provision [2].

c. Law 1150 of 2007 in article 29 defines the elements that all state contracts for street lighting should abide [3].

d. Article 191 of Law 1753 of 2015 "National development plan 2018-2022 'Todos por un nuevo país" states that street lighting "(...) is an essential public service, ruled by articles 56 and 365 of the Political Constitution. National Government, through the Ministry of Mines and Energy, shall regulate their provision to be ensured by municipal and district authorities." [4].

e. The Ministry of Mines and Energy through Resolution 181331 of 2009 issued the Technical Regulation for Illumination and Street Lighting, RETILAP, modified by Resolutions 180265, 180540, 181568 and 182544 of 2010 [5].

f. According to section 580 of the Technical Regulation for Illumination and Street Lighting (RETILAP) of resolution 180540 of March 30, 2010 from the Ministry of Mines and Energy "Municipalities that have registered in their street lighting infrastructure database over five thousand (5000) lighting points, should provide a web query system with the information of street lighting in operative and customer service areas [5].

(a)

(b)

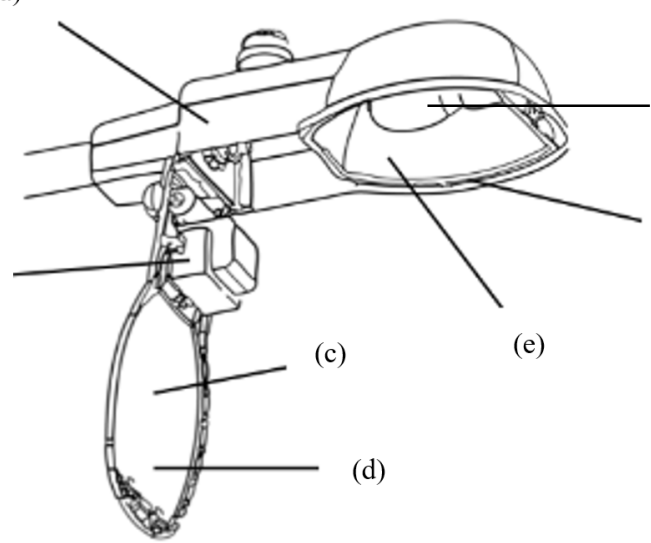

FIG. 1 Street luminaire: (a) mounting (b) electrical equipment, (c) filter, (d) diffuser, (e) reflector, (f) junction box and $(\mathrm{g})$ lightbulb.

(g)
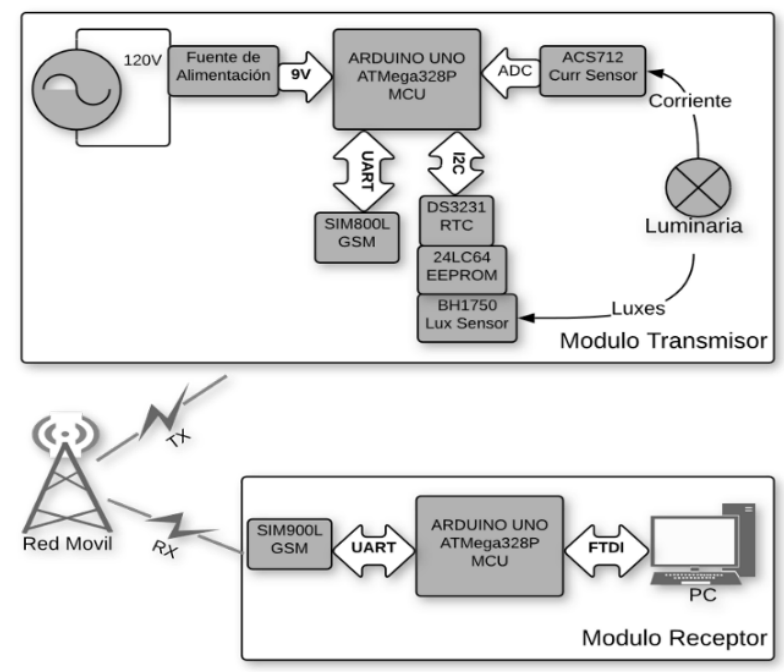

FIG. 2 Monitoring system block diagram.

Considering the described legal frame, development of this prototype is important, since through implementing a monitoring system in a lighting point for a street lighting circuit one can ensure that truthful and opportune information on the luminaire performance can be obtained in real time. These data will determine faster the system status, enabling the optimization of the maintenance routes, disposition of economic resources and the times for attention failure fixes. Therefore, for the adaptation of the monitoring system to the previously described requirements, it must be developed as a flexible embedded system, with low cost 
and implementation time ; this makes quick prototype platforms such as Arduino or Mbed ideal for this application, also considering that the $y$ already include prepared libraries for integration of different hardware modulus that will conform the whole system [6], [7].

A street lighting luminaire consists of: Case or armor, where the different components are integrated; Electrical equipment, constituted of the start and operation elements; Reflector, in charge of directing light in a desired direction; diffusor, where a screen is incorporated in order to avoid glare; filter, in charge of diminishing the distortion produced by UV and infrared radiation; juncture, which avoids water entering the device; and bulb, which can be incandescent, fluorescent, metal-halide, sodium, among others [8], such as illustrated in Fig. 1. Likewise, inside the electrical equipment AC/DC converters are required, operating at high frequency in order to increment their efficiency with respect to electric power use. These converters are present as a load in a resonant circuit, where the current suppled to the luminaire [9][10].

Some antecedents on the international level show that exists an interest in developing monitoring systems, such case as the patents US7333903B2 [11] and US7603184B2 [12], which consist on the diagnostics of failures in luminaires from measurement of variables as voltage and current, allowing to estimate their consumed active power. Additionally, other authors have developed a control and monitoring system for LED lamps on street lighting, in order to conduct an efficient energy management of the luminaires; this system has a Doppler effect sensor for proximity detection of vehicles and/or pedestrians, to consequently modulate the light intensity of the lamps, as well as a current sensor to identify possible failures. This type of systems, as well as the developed in this article, is framed in the concept of Smart Cities [13].

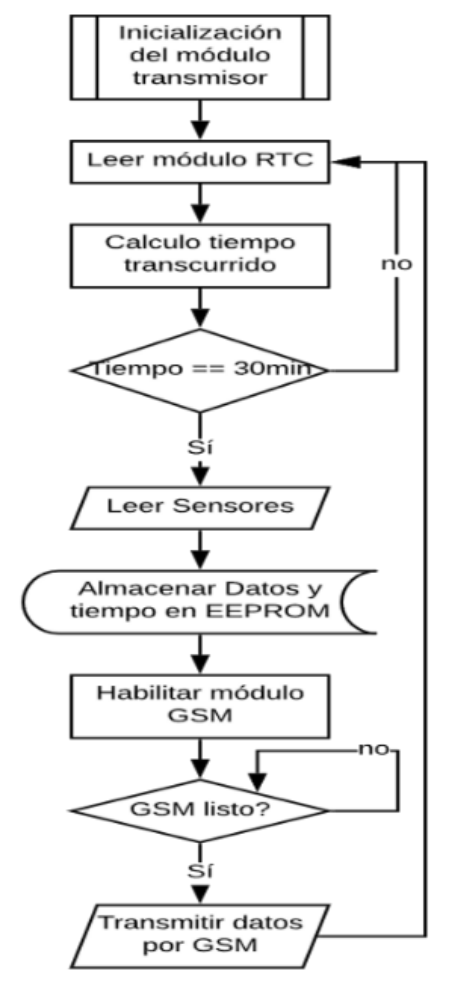

FIG. 3 Transmitter's (TX) flowchart.

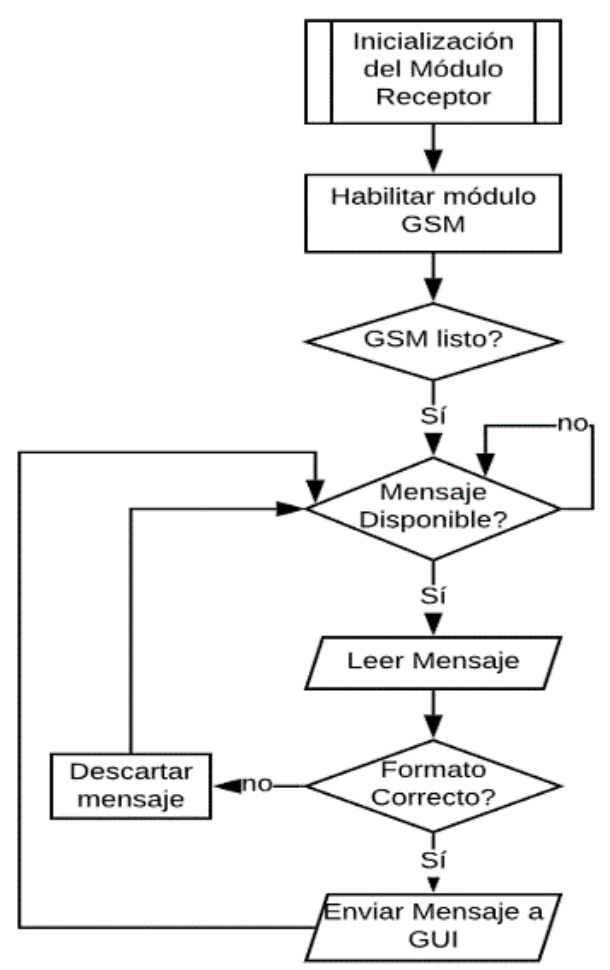

FIG. 4 Receiver's (RX) flowchart.

In Latin America, the conducted works are focused towards street lighting lamps management, controlling remotely the switching on and registering the time during such state, with the purpose of estimating their remaining hours of useful lifetime; this monitoring is achieved through short range radio frequency (RF) connections [14]. Specifically in Colombia, a related precedent was found, where a prototype for an illuminance sensor is designed with a slave-microcontroller for each lamp, in charge of sending the data solicited by a mas- 
ter through a RS485 network; Then the master sends the data to a monitoring station via Ethernet network [15].

In consulted antecedents we identified a series of drawbacks, such as wired networks that presume an additional difficulty in case of an eventual full-scale system installation. In other cases, is evidenced the absence of measurement of variables as light efficiency or lamp consumption.

According to this, the objective for this work is to design and implement a lab prototype that enables to measure and transmit the most relevant variables on the luminaires operation state; For this, the capacity and system maintenance data are analyzed, corresponding to two municipalities in Caldas, and we determine the most common failures in these devices. Also, we identify the thresholds for light efficiency allowed by the legislation and operation tests are conducted under different operation points during their useful lifetime.

\section{2 | MATERIAL AND METHODS}

First, real data for the luminaires' behavior must be analyzed, in electrical and atmospheric conditions to which they are exposed, this for getting a clear idea of which are the most recurrent failures and once detected. Information was provided by the company in charge of providing maintenance of the street lighting service Central Hidroeléctica de Caldas (Hidroelectric Central of Caldas, CHEC). Thus, we were able to perform the corresponding analysis for 30 months, comprehended between July 2013 and December 2015, also taking into account the municipalities of Riosucio and Aranzazu (Caldas), considering their respective luminaire capacities (see Table 1). We were able to establish that the most common lamp in both municipalities is the sodium $70 \mathrm{~W}$ light bulb, which equals the $59.45 \%$ of installed lighting points [16]. Below we describe the considered information for this research's development.

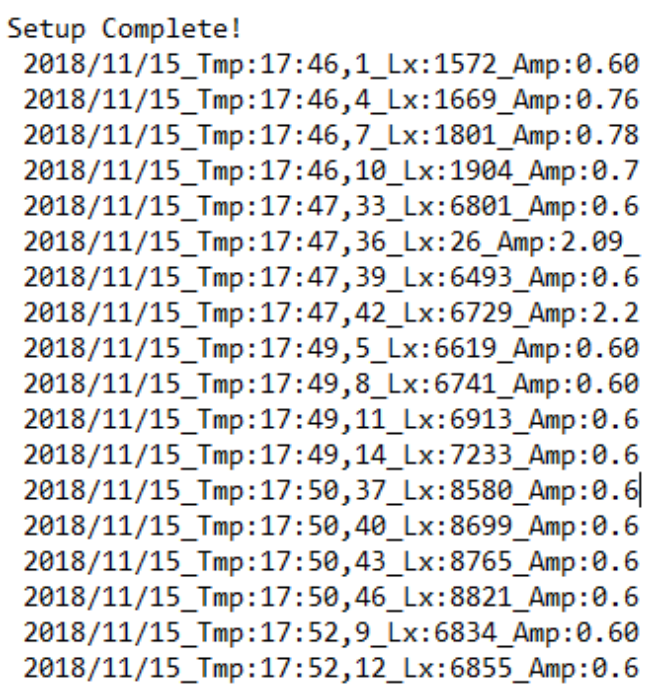

FIG. 5 Software serial port.

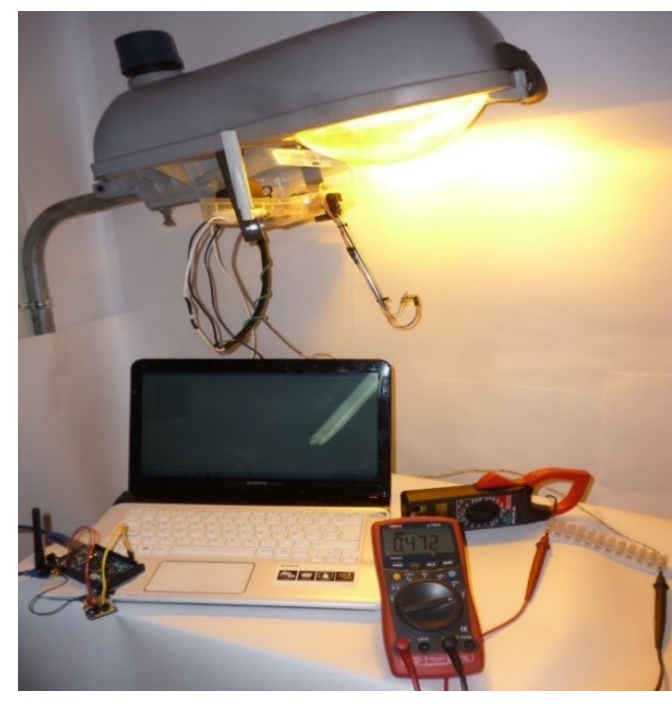

FIG. 6 Final prototype and elements for comparison measurements.

\section{1 | Street lighting maintenance format}

Through this document is possible to obtain information about the type of failure in the luminaire:

1. Luminaire is On during the day

2. Luminaire is Off during the night

3. Intermittent luminaire

4. Broken luminaire 
5. Preventive maintenance

Once analyzed the information, we evidence which are the most frequent failures (see Table 2). Considering that 3188 maintenance formats were revised, $73.1 \%$ of those correspond to corrective type. In more detail, $58 \%$ correspond to luminaires switched off during nighttime, $10.4 \%$ to luminaires switched on during daytime and $4.7 \%$ between intermittent and broken luminaires, with which the company is incurring in breach and faces possible sanctions, since only $26.9 \%$ (failure 5 on Table 2 ) is reflected in preventive maintenance. This study shows the need of incrementing efficiency in the service quality and provision [16].

\section{2 | Material supplies record}

Same as with the filled-out formats in the previous section, of which the supplies and materials database, we analyze the information containing stock movement of luminaire components. This in order to determine the elements which most frequently fail, corresponding to the $70 \mathrm{~W}$ lamps and the photo-control module. Is intended then to monitor the failure type 2, consisting on luminaire off during night, and failure type 1 , corresponding to luminaire on during day. Is important to clarify that within the replaced light bulbs, were also considered intermittent and broken luminaires corresponding to failures 3 and 4 on Table 2.

TAB LE 1 Luminaires capacity according to type, power, losses and total load.

\begin{tabular}{|c|c|c|c|c|}
\hline \multicolumn{5}{|c|}{ LUMINAIRES TOTAL CAPACITY FOR BOTH MUNICIPALITIES } \\
\hline Type & $\begin{array}{l}\text { Power } \\
\text { (W) }\end{array}$ & Losses (W) & Quantity & Total Load (W) \\
\hline \multirow{2}{*}{$\begin{array}{l}\text { Incand } \\
\text { escent }\end{array}$} & 106 & 0 & 1 & 106 \\
\hline & 300 & 0 & 1 & 300 \\
\hline $\begin{array}{c}\mathrm{FL} \\
\text { (Fluore } \\
\text { scent) }\end{array}$ & 150 & 19 & 4 & 676 \\
\hline \multirow{4}{*}{$\begin{array}{c}\text { MH } \\
\text { (Metal- } \\
\text { Halide) }\end{array}$} & 70 & 11 & 1 & 81 \\
\hline & 150 & 19 & 1 & 169 \\
\hline & 250 & 21 & 1 & 271 \\
\hline & 1000 & 54 & 1 & 1054 \\
\hline \multirow{6}{*}{$\begin{array}{c}\text { Sodiu } \\
\text { m }\end{array}$} & 50 & 10 & 2 & 120 \\
\hline & 70 & 11 & 1366 & 110646 \\
\hline & 125 & 14 & 3 & 417 \\
\hline & 150 & 19 & 561 & 94809 \\
\hline & 250 & 29 & 354 & 98766 \\
\hline & 400 & 40 & 3 & 1320 \\
\hline \multicolumn{3}{|c|}{ General Capacity } & 2299 & 308735 \\
\hline
\end{tabular}

\section{3 | First test}

In this section we conduct illuminance measurement tests (luxes or "Ix") in 70W lamps, both new and used. These values were measured with a "Lutron LX-105" luxometer with valid calibration certificate. First step is to connect all luminaire components shown in Fig. 1, and then fasten the luminaire case to a tube. We also use a "HIOKI 3280-10" volt-amperimetric clamp meter, with which we measure values of demanded current in the lighting point. Additionally, we use a "UNI-T UT61C" multimeter, connected in series to a power supply phase, with the purpose of comparing the measured value to the one obtained with the AC clamp. For an appropriate use of the luxometer, is required to guarantee the same conditions to which the sensor in the prototype is submitted to, i.e. location at a given distance $(28 \mathrm{~cm}$ for this test) and constant angle (90 degrees) with respect to the lamp. Data obtained in this test is appreciated in Table 3, where such values will be useful to establish the number of lamps within their useful life or beyond such point, as shown on Table 
4 and described below. 13 tests were conducted with 70W lamps of the same brand, and 3 of these were performed with new lamps serving as a reference parameter for light efficiency at $100 \%$ (average 13018.667 $\mathrm{Ix}$ ), considering that RETILAP stipulates that all luminaire electrical components below an efficiency of $70 \%$ must be replaced. For the $70 \mathrm{~W}$ lamp according to the conducted tests, corresponds to a minimum value of $9113.066 \mathrm{~lx}$. Is observed that, out of ten conducted tests on used light bulbs, taken down by the maintenance crew, nine are below permitted minimum range, and four are below $50 \%$ light efficiency, which indicates an inadequate service provision. Furthermore, in spite of not complying with the stablished luminous flux, the consumption of current is still the same. In Table 3 we show values of current in used light bulbs (0.463 A) similar to the ones in new lamps (0.466 A).

\subsection{Selection of suitable components}

Once known the values for illuminance $(\mathrm{Ix})$ and current $(\mathrm{A})$, to which the $70 \mathrm{~W}$ luminaire is submitted, we determine which are the most suitable elements for the development and implementation of the monitoring system.

\subsection{1 | Microcontroller}

Searching for a central process unit that allows interaction between devices, such as signal transmitter or receiver, we evaluated and compared datasheets for the following development boards: Arduino UNO and Arduino MEGA 2560. There are similarities between both development systems, although the advantage for Arduino MEGA 2560 is that it has more Universal Asynchronous Receiver Transmitter (UART) ports. This is important for the receiver modulus, where two of these ports are required. On the other hand, Arduino UNO has enough specifications for implementation of the transmitter modulus, which requires only one UART port and an Inter-Integrated Circuit (I2C) bus [17].

TAB LE 2 Compilation of public lighting maintenance formats.

\begin{tabular}{|l|c|c|c|c|c|}
\hline Failure Type & Luminaire On during the day & Luminaire Off during the night & Intermittent Luminaire & \multicolumn{2}{c|}{ Broken Luminaire } \\
\hline Code & 1 & 2 & 3 & 4 \\
\hline Quantity per Failure & 330 & 1851 & 127 & 22 \\
\hline Revised formats & & & 3188 & 858 \\
\hline
\end{tabular}

\subsection{2 | Current sensor}

Taking into account the values for current obtained in tests, we consider both the switch-on instant as well as the normal operation current values of $2.8 \mathrm{~A}$ and $0.5 \mathrm{~A}$ respectively. Knowing these values, we can establish that the current sensor ACS712 complies such requirements (see Table 5). This sensor has a 30A capacity, which allows a tolerance in case of failure for protecting the sensor itself, and its sensitivity is $66 \mathrm{mV} / \mathrm{A}$. On the other hand, its principle of current measurement is through Hall effect, which makes it immune to temperature changes and compatible to the Analog to Digital Converter, ADC, in the microcontroller [18].

\subsection{3 | Illuminance sensor}

Likewise, we consider the experimentally obtained data, with reference to emitted luxes by new $70 \mathrm{~W}$ lamps (average $13018.667 \mathrm{~lx}$ ), starting from the maximum value presented in the lighting point, we chose for implementation the Bh1750 illuminance sensor. In particular, this device is capable of measuring between 1 and $65535 \mathrm{~lx}$ in high definition, and even can be modified for a range between 0.11 and $100000 \mathrm{~lx}$, if required. Both intervals cover the value present in light bulbs, not to mention that is compatible with the microcontroller, since the data can be extracted through I2C protocol [19] 


\subsubsection{Communication}

Since the objective is to design and implement a device that allows to monitor the operation of a luminaire, is required to incorporate to the prototype a modulus in charge of transmitting and receiving data. In this case the SIM800L and SIM900L Global System for Mobile Communications (GSM) modulus were chosen, which connect to mobile phone networks in GSM frequencies: $850 / 900 / 1800 / 1900 \mathrm{MHz}$ and gives an option to add SMS messaging. Communication with microcontroller is performed through UART protocol and AT commands [20].

\subsection{5 | Data storage}

There is a great variety of devise that provide a wide flexibility in use and enable stored data acquisition at any given time. In this case, an Electrically Erasable Programable Read Only Memory (EEPROM) chip as non-volatile storage device, specifically the 24LC64 reference, which communicates with the microcontroller through $12 \mathrm{C}$ data bus. This enables a back-up for the last current and illuminance data, in case of failures in communication or power supply.

TAB LE 3 Illuminance and Current values.

TAB LE 4 Percentage of Illuminance efficiency and

\begin{tabular}{ccccc}
\hline ITEM & LAMP & $\begin{array}{c}\text { LUXOMETER } \\
(\mathrm{lx})\end{array}$ & $\begin{array}{c}\text { MULTIMETER } \\
(\mathrm{A})\end{array}$ & $\begin{array}{c}\text { AC } \\
\text { CLAMP } \\
(\mathrm{A})\end{array}$ \\
\hline 1 & New & 13134 & 0,466 & 0,44 \\
2 & New & 13032 & 0,465 & 0,46 \\
3 & New & 12890 & 0,467 & 0,45 \\
4 & Used & 10567 & 0,467 & 0,44 \\
5 & Used & 7921 & 0,454 & 0,42 \\
6 & Used & 7844 & 0,477 & 0,44 \\
7 & Used & 7643 & 0,486 & 0,45 \\
8 & Used & 7023 & 0,459 & 0,42 \\
9 & Used & 6098 & 0,459 & 0,42 \\
10 & Used & 6348 & 0,467 & 0,43 \\
11 & Used & 5415 & 0,458 & 0,42 \\
12 & Used & 6849 & 0,46 & 0,41 \\
13 & Used & 5645 & 0,447 & 0,41 \\
\hline
\end{tabular}

\begin{tabular}{lcc}
\hline \multicolumn{1}{c}{ ITEM } & Luxes (lx) & Used within range \\
& & \\
\hline Average Efficiency $100 \%$ & 13018.667 & 0 \\
Average Efficiency $70 \%$ & 9113.0667 & 1 \\
Average Efficiency $60 \%$ & 7811.2 & 2 \\
Average Efficiency 50\% & 6509.3333 & 3 \\
Average Efficiency 40\% & 5207.4667 & 4 \\
Average Efficiency 30\% & 3905.6 & 0 \\
Average Efficiency 20\% & 2603.7333 & 0 \\
\hline Used maximum value & 10567 & \\
Used maximum value & 5415 & \\
Average current for new & 0.466 & \\
lamps & & \\
Average current for used & 0.4634 & \\
lamps & &
\end{tabular}

\section{5 | Prototype elaboration and operation}

Once the different components for the system modulus are selected, considering stablished values in first test, we list below the elements belonging to the transmitter device (see Fig. 2):

- $\quad$ Development board (Arduino UNO).

- $\quad$ Illuminance sensor (Bh1750).

- $\quad$ Current sensor (ACS712).

- $\quad$ Real Time "RTC" modulus (DS3231).

- $\quad$ External EEPROM memory (24LC64).

- $\quad$ Communication modulus (GSM SIM800L) + 6 dB antenna.

These devices are connected to the central microcontroller through different serial protocols: 
- $\quad \mathrm{I} 2 \mathrm{C}$ bus in the case of lux sensor, real time modulus and EEPROM memory. An access address is assigned to each of them for differentiation, since Arduino UNO only has one I2C bus. Specifically, Bh1750 sensor is configured for a range between 1 to $65535 \mathrm{Ix}$ for obtaining the best possible resolution from this 16-bit sensor.

- $\quad$ UART interface for the GSM modulus, which takes his orders from the microcontroller through AT commands. List of supported commands by the SIM90OL modulus can be found in [20].

- $\quad$ ACS712 sensor is connected directly to the Arduino ADC, which has a 10-bit resolution. This allows discrimination of changes up to $74 \mathrm{~mA}$ in the lamp's current. Sensor bandwidth is more than enough, since operation will be with line frequencies, and RMS current values are obtained through a peak detection algorithm in the microcontroller [21].

TAB LE 5 Values for Illuminance and Current.

\begin{tabular}{|c|c|c|c|c|c|c|}
\hline ITEM & LAMP & $\begin{array}{c}\text { LUXOMETER } \\
(\mathbf{( x )}\end{array}$ & $\begin{array}{c}\text { BH 1750 } \\
(\mathbf{( x )}\end{array}$ & $\begin{array}{c}\text { MULTIMETER } \\
(\mathbf{A})\end{array}$ & $\begin{array}{c}\text { CLAMP } \\
\text { METER (A) }\end{array}$ & $\begin{array}{c}\text { ACS712 } \\
(\mathbf{A})\end{array}$ \\
\hline 1 & New & 13134 & 12846 & 0.476 & 0.47 & 0.53 \\
\hline 2 & New & 13032 & 12850 & 0.475 & 0.45 & 0.82 \\
\hline 3 & New & 12890 & 12515 & 0.457 & 0.43 & 0.75 \\
\hline 4 & Used & 10567 & 10234 & 0.483 & 0.45 & 0.59 \\
\hline 5 & Used & 7921 & 7320 & 0.451 & 0.41 & 0.68 \\
\hline 6 & Used & 7844 & 7267 & 0.481 & 0.44 & 0.54 \\
\hline 7 & Used & 7643 & 7225 & 0.481 & 0.46 & 0.77 \\
\hline 8 & Used & 7023 & 6987 & 0.432 & 0.42 & 0.95 \\
\hline 9 & Used & 6098 & 5974 & 0.442 & 0.43 & 0.65 \\
\hline 10 & Used & 6348 & 6255 & 0.448 & 0.43 & 0.78 \\
\hline 11 & Used & 5415 & 5680 & 0.464 & 0.42 & 0.57 \\
\hline 12 & Used & 6849 & 6723 & 0.472 & 0.43 & 0.66 \\
\hline 13 & Used & 5645 & 4855 & 0.465 & 0.46 & 0.56 \\
\hline \multicolumn{2}{|r|}{ SUMATORY } & $\mathbf{1 1 0 4 0 9}$ & $\mathbf{1 0 6 7 3 1}$ & $\mathbf{6 , 0 2 7}$ & $\mathbf{5 . 7}$ & $\mathbf{8 . 8 5}$ \\
\hline \multicolumn{2}{|l|}{ ERROR \% } & & & ERROR \% & & $-\mathbf{4 6 . 8 4}$ \\
\hline
\end{tabular}

Firmware developed for Arduino in emitter modulus, as shown on Fig. 3, consists on a time reading sequence from the Real Time Clock modulus (RTC). Then, this time is compared with the one recorded on the previous sensor reading and when 30 minutes have passed, a new sensor reading is performed and the corresponding data is stored in the EEEPROM memory and transmitted via SMS with date, time, and luminaire luxes and current data.

The receiving modulus, also shown in Fig. 2, consists on an Arduino MEGA, a SIM900L modulus connected through a UART interface, and a PC where the data coming from the luminaire is received and visualized, as shown on Fig. 5. The firmware programmed on Arduino MEGA, as shown in figure 4, consists on enabling the GSM modulus and then a verification sequence of new messages. Additionally, the new message format is validated and sent to a serial monitor in the PC.

All elements corresponding to the prototype structure satisfy tension, current, luxes and communication levels $[17,18,19]$. 


\section{3 | RESULT}

Once the different components are connected and coupled to the luminaire, we validate the proper operation through the measurement obtained for the implemented prototype. Equipment used in the first test are the same used in this section, as shown in Fig. 5, ensuring the same operation conditions. Ten tests were conducted, conformed by seven used and three new light bulbs (see able 5), evidencing similar values between the luxes from the Bh1750 sensor and the luxometer, with an error percentage of 33\%, while between the current values provided by the ACS712 sensor and the multimeter are different, with an error percentage of $-46.83 \%$. we should note that the obtained value is an average, since if it is compared measurement by measurement, to the reading of ten separate values, five of them are close to the multimeter reading. This difference is mainly due to the algorithm implemented in the code, which has been used for computing peak to peak voltage from the set of measurements taken by the current sensor from the microcontroller's ADC, and/or from the noise embedded in the signal caused by the light bulb's temperature.

Also, the non-compliancement of the rule is evidenced when to illuminance levels is referred, as shown in Table 5, since in the RETILAP regulation is stated that all electrical components in a luminaire below a 70\% efficiency must be replaced. For the case of a $70 \mathrm{~W}$ lamp, which corresponds to a minimum value of 8915.9 $\mathrm{Ix}$, out of ten tests conducted on used light bulbs, removed by the maintenance group, nine were found below the allowed range and even four of them were below 50\% efficiency. Additionally to not complying with the stablished luminous flux, the consumption is still the same, given that current values in used light bulbs $(0.65$ A) are similar in contrast with new light bulbs $(0.7 \mathrm{~A})$.

\section{4 | CONCLUSIONS}

Is possible to design and implement a device that allows to monitor in real time the operation of an element, in this case a lighting point.

By having a system that gives illuminance values, is possible to conduct preventive maintenance that helps on the regulation compliance for the street lighting service (minimum 70\% efficiency, as stated by RETILAP), according to the obtained laboratory values through the created system, this would be $8915.9 \mathrm{Ix}$ for a $70 \mathrm{~W}$ Sodium light bulb.

The prototype is within the required needs, with an operation similar regarding to luxes measurement, contrasted with other measurement tools. This device not only would decrease low luminance, but also could detect recurrent failures in the system, such as luminaires being switched off during the night or switched on during the day.

For all practical purposes, regarding to communication (transmitting and receiving), the device has good coverage since it uses mobile phone networks, which makes this able to monitor from anywhere in the world.

With the monitoring system, we would not have light bulb removals in levels within useful life, reducing costs, guaranteeing the proper operation and compliance of stablished regulations for street lighting service.

Current values provided by the measurement elements, UNI-T UT61C Multimeter and HIOKI 3280-10 Volt-Amp Clamp Meter, compared with the values from the ACS712 sensor differ in $46.84 \%$. This indicates the need to improve the code's structure, in order to decrease the error percentage to values below $5 \%$.

\section{FUTURE WORK}

With this system is possible to perceive the power of creating an interface, among numerous replica of this prototype, intertwining them and processing their information through a server, using a software that allows filtering and depuration of information in such a way that, by coding the luminaires, it detects the determining variables such as minimum allowed luxes values, luminaire off during night or luminaire on during day. From the detection of this failure, specific work routes can be proposed with an a priori knowledge of the state of an specific ser of luminaires. 


\section{References}

[1] Salazar, Q. S.-I.-E. (Diciembre de 2015). Universidad Tecnológica de Pereira. Sistema para el Monitoreo Remoto de la Temperatura en Transformadores de Distribución. Pereira, Colombia.

[2] Energía, M. d. (1 de Abril de 2010). RETILAP. Reglamento Técnico de iluminación y Alumbrado Público. Bogotá, Colombia.

[3] Constitución política (1991) estado colombiano. CARTA MAGNA O CARTA FUNDAMENTAL. BOGOTA COLOMBIA.

[4] MINAS Y ENERGIA (1940) MINISTERIO DE MINA Y ENERGIA. oficina estatal que se encarga de dirigir la política nacional en cuanto a minería, hidrocarburos e infraestructura energética. BOGOTA COLOMBIA.

[5] CHEC. (Mayo 2013 a Diciembre 2015). Concesión de Alumbrado Público Riosucio y Aránzazu. Manizales.

[6] ARDUINO (2006) Instituto IVREA, PROYECTO PARA ESTUDIANTES. Ivrea (Italia).

[7] Sensor de corriente ACS 712. características. Arduino.

[8] Sensores de luxes BH1750. Arduino.

[9] J. F. Bayona Navarro, J. Edwin Vera Vera, and N. Y. Gelvez Garcia, "Implementation of a series resonant inverter to improve fluorescent lamp efficiency," TECCIENCIA, vol. 11, no. 21, pp. 7-12, 2016. doi: 10. 18180/tecciencia.2016.21.2

[10] Ethernet W5100, Shield Arduino.

[11] GSM "SIM800L y SIM900L", Shield Arduino.

[12] BLUETOOH HC-06. Arduino.

[13] J. Acevedo, "Universidad nacional de colombia. marco teórico de la tele gestión del servicio de alumbrado público," 2010.

[14] A. Arroba, "Escuela politécnica nacional. construcción de un luxómetro digital," 2007-09.

[15] R.-C. Garriga, "Universidad politécnica de cataluña. diseño de una aplicación de software de medición y evaluación de niveles de iluminación en vía pública mediante gps," 2011.

[16] D.-M.-I.-D. Hoya, "Universidad autónoma de ciudad juárez. nodo sensor inalámbrico para medir iluminación," Mayo - Agosto de 2015.

[17] G.-J.-O. Jaramillo, "Universidad de san buenaventura. tele gestión del alumbrado público de medellín," 2009.

[18] Q.-I.-E. Salazar, "Universidad tecnológica de pereira. sistema para el monitoreo remoto de la temperatura en transformadores de distribución," 2015.

[19] D. Sánchez, "pontificia universidad católica del perú. diseño y desarrollo de un sistema de iluminación automatizado para el hogar usando tecnología zigbee y controlado inalámbricamente desde un servidor web," 2015.

[20] R. Tomalá, "Escuela politécnica del ejército. diseño e implementación de un sistema automatizado para control remoto de iluminación en conformidad de la tecnología insteon y optimización del sistema de seguridad cctv en el edificio gimpromed," 2012-03. 